\title{
Malva verticillata L. and Vicia hirsuta (L.) S.F. Gray - invasive Species of Siberia (Overview)
}

\author{
S.I. Mikhailova and A.L. Ebel \\ National Research Tomsk State University, 36 Lenina Avenue, Tomsk, 634050, Russia. \\ DOI: http://dx.doi.org/10.13005/bbra/1872 \\ (Received: 16 September 2015; accepted: 06 November 2015) \\ The article provides an overview of information on the two invasive species of \\ Siberia that are weeds of crops - Malva verticillata L. and Vicia hirsuta (L.) S.F. Gray. It \\ provides information on the distribution of species, morphology, biological and ecological \\ characteristics. Active ability of Vicia hirsuta to spread with the seed of oil plants and \\ honey plants was revealed. The possible consequences of the introduction in natural \\ plant communities are shown. The possibility of the practical use of these species as \\ fodder, food and medicinal plants is considered.
}

Key words: invasive species, Malva verticillata, Vicia hirsuta, Siberia, distribution, speirochoria.

Currently, weed-field (segetal) plant species are an important component of agrocoenosis in Russia. Species composition and abundance of weeds in agricultural crops largely determine the efficiency and quality of the crop production. Weeds are an annual permanent factor that reduces the yield of economically valuable products, such as cereals - by $20-25 \%$, and vegetables - by $50 \%$. Major changes in farming systems and technologies of cultivation of agricultural crops in Western Siberia that have taken place in recent decades could not affect the change of segetal vegetation and especially the species composition of weeds (Vlasenko et al., 2007). It should be noted that the recent extensive studies of weeds in agrocoenosis of Tomsk region were conducted in 50th of XX century (Polozhij, 1954). There is an acute problem of penetration in various ways new weeds, including invasive species.

The problem of invasive species is one of the most actual in the biology and ecology

\footnotetext{
* To whom all correspondence should be addressed. Tel.: +7 9039529145

E-mail: mikhailova.si@yandex.ru
}

(D’Antonio, Meyerson, 2002; Richardson et al., 2007). It is known that invasion of the invasive species leads to a reduction of biological diversity (Hejda, Pysek, 2006; Winter et al., 2009). However, the invasion of "harmful" alien species caused great damage not only to natural ecosystems, but also to the economies of developed and developing countries (Pimentel et al., 2001, 2005; Nghiem et al., 2013). In recent years, the interest to the study of invasive plant species in the European part of Russia has significantly increased. In particular, the evidence of this are the recently published monograph, "Black Book of flora of Central Russia" (Vinogradova et al., 2010), "Black Book of flora of the Tver region” (Vinogradova et al., 2012) and others. In the Asian part of Russia, including Siberia, such work is only beginning. One of the first results is a recently published list of invasive and potentially invasive plant species of the Siberian Federal District (Ebel et al., 2014).

The present report summarizes two invasive species, previously widely grown in culture, and now actively spread over the southern regions of Siberia and often infests crops. 


\section{MATERIALSAND METHODS}

Review the information on the two types of invasive species in Siberia - Malva verticillata L. and Vicia hirsuta (L.) S.F.Gray is based on the analysis of the field data, herbarium material and literature databases on weedy and invasive plants. We studied herbarium materials of these types stored in the herbarium of Tomsk institutions (P.N. Krylov Herbarium, TK), Novosibirsk (Herbarium of the Central Siberian Botanical Garden, NS; M.G. Popov Herbarium, NSK), Barnaul (Herbarium of the Altai State University, ALTB), Kemerovo (Kuzbass Botanical Garden Herbarium, KUZ) and Krasnoyarsk (Herbarium of the Krasnoyarsk pedagogical University, KRAS). We collected and analyzed information about the new location that was discovered in the last decades on the territory of Siberia.

Field floristic studies were carried out in 1990-2015 years in Siberia (Tomsk Region, Kemerovo Region, Novosibirsk Region, Altai Territory, Republic of Altai, Republic of Khakassia). Infestation of the 50 seed lots of oil plants and honey plants (Brassica napus, Phacelia tanacetifolia, Sinapis alba) by weeds was studied. Seeds from each batch of primary cultures were taken in average sample weight of 1 to $2 \mathrm{~kg}$ from which we allocated all weed seeds. Identification of weed species was carried out with the main morphological characters of fruits, whole seeds and partially collapsed seeds (Maisuryan, Atabekova, 1978; Brouwer, Shtelin, 2010).

\section{RESULTS}

Malva verticillata $\mathbf{L}$. (M. pulchella Bernh., $M$. mohileviensis Dovnar)

Annual plant 35-150 cm tall. Stems are solitary or few in number, straight or ascending, usually branched, glabrous or pubescent in the upper part. Leaves are long, petioles are usually 25 times the length of the plate, hairy. The plates are 3-7 cm long and 4-12 cm wide, kidney-shaped, at the basis deeply cordate, 5-7-lobed, crenatetoothed on margin, glabrous or sparsely hairy, usually in the bottom are along veins pubescent, rarely glabrous or with a few simple, bifurcated or stellate hairs. Flowers are numerous, almost sessile, clustered in the glomeruli in the leaf axils. Calyx is divided into 5 ovate-triangular pointed stakes, covered with long simple and short stellate hairs. Corolla is 1.5-2 times higher than the calyx, purple and violaceous in the dry state. Petals are 6-8 mm long, obovate, notched, fringed at the basis. Staminate tube is with directed downward hairs. Fruitlets in number 10-11 are assembled in a circle with a diameter of 7-10 mm, with bare dorsally wrinkled walls (Vlasova, 1996).

It is a very polymorphic species, sometimes is divided into several intraspecific taxa, to which some researchers give the species rank (Danert, 1966). One of these taxa is M. verticillata var. neuroloma Schlecht. (= Malva mohileviensis) characterized by long petiolate leaves with shallow-cordate at the base plates and flat on the edge of the obtuse lobes S.K. Cherepanov (1995) considered $M$. mohileviensis as synonymous of the Linnaean species Malva verticillata. However, according to the "Flora of Eastern Europe", the real $M$. verticillatav in Siberia is missing: here is widely spread another species, formerly known as M. mohileviensis, but his priority name is $M$. pulchella (Olyanitskaya, Tzvelev, 1996). Later, one of these authors (Tsvelev, 2000), considered more appropriate to relegate $M$. pulchella to subspecies: Malva verticillata subsp. pulchella (Bernh.) Tzvel. In modern nomenclature databases (The Plant List, 2013; Tropicos..., 2015) and floristic reports (Majevski, 2006; Ya et al., 2007; Majorov et al., 2012) the name of M. pulchella is reduced to synonyms for the name $M$. verticillata.

The homeland of $M$. verticillata. L. is probably China (Olyanitska, Tsvelev, 1996). Secondary area includes temperate and subtropical areas of Eurasia, North America, Africa, Australia (Kloot, 1983; Ya et al., 2007; Randall, 2012). It is widely distributed in North America (PLANTS Database, 2015) where it is considered as an invasive species (Ya et al., 2007).

In Europe, M. verticillata is one of the diagnostic species of class Stellarietea mediae Tx. Et al. ex von Rochow 1951 (Mucina, 1997), which includes segetal and ruderal communities of annual plants, representing the initial stages of restoration succession after disturbance of the soil cover.

In Siberia, the species was first found in 1896 in Tomsk (Krylov, 1933). In Western Siberia until recently it was known to relatively few locations in the Omsk, Novosibirsk, Tomsk, 
Kemerovo and Altai regions (Koroleva et al., 1973; Vlasova, 1996; Krasnoborov, 2001; Silantieva, 2006; Shaulo et al., 2010). Now it is a fairly common weed in the south of Western Siberia, where it grows in gardens and orchards, landfills, wasteland, railway embankments, roadsides (Ebel, 2012).

In the last quarter of the XX century $M$. verticillata was found in Khakassia (Serykh, 1977, Ebel, Nekratova, 1996). Recently it was recorded for Tuva (Shaulo et al., 2006). In addition, this mallow is quite widespread in the southern regions of Eastern Siberia (Vlasova, 1996), where it appeared near the middle of the XX century (Popov, 1957). Probably, now $M$. verticillata is actively expanding its range. There is a possibility of penetration with seeds of cultivated plants. In areas where $M$. verticillata is cultivated as a forage plant, it may run wild.

Malva verticillata is an annual plant of a spring type. It is a mesoxerophyte. The plant developed slowly during germination - booting stage, which lasts 35-40 days. Since the phase of budding the growth is accelerating. In the flowering period (July-September) it generates greater assimilation surface (41.8 thousand. $\mathrm{m}^{2} / \mathrm{ha}$ ) and has a high rate of net photosynthetic productivity (4.22 $\mathrm{g} / \mathrm{m}^{2}$ ) (Rakhmetov, 1993). The species is crosspollinated, and is propagated by seeds. Under the conditions of forest-steppe of Ukraine it is necessary 64-69 days for fruiting. Under the conditions of the south of Tomsk region, the length of the vegetation period is $80-90$ days. Seeds have a large embryo and endosperm. Freshly harvested seeds are in a state of physical dormancy caused by water resistance of the seed coat (Nikolaev et $a l ., 1985)$. To interrupt the dormancy it is necessary processing them through scarification. According to our data the seeds of $M$. verticillata collected in Khakassia in 2014 (Shirinsky district, village Efremkino) after 6 months of a dry storage at room temperature have a high viability (95\%). Germination of non-scarified seed was $29 \%$, and scarified ones - $84 \%$.

$M$. verticillata is actively spreading on fallow lands. High seed production and the presence of physical dormancy ensure the creation of long-term soil seed bank.

Because of its high yields of aboveground mass and capacity for intensive wear of soil nutrients (nitrogen, potassium, calcium and phosphorus), this species can greatly impoverish the soil (Kasarin et al., 2009).

Along with the negative consequences of the spread of $M$. verticillata in Siberia, it should be noted also the possibility of practical use of this species. $M$. verticillata is a promising fodder crop; it can be used for hay, hay meal and grass meal (Kasarin et al., 2009). The grass meal contains a lot of carotene (11-20 mg\%), protein (20\%) and minerals and nutritional value of $1 \mathrm{~kg}$ of the flour is 0.7-0.8 feed units. $100 \mathrm{~kg}$ of green mass contains up to 22-24 fodder units and about 3-4 kg of digestible protein, or from 116 to 180 g per fodder unit. The digestibility of the protein is $75.0 \%$, fat $28.6 \%$, fiber $33.0 \%$, nitrogen-free extractive substances - $65.6 \%$, and organic substances $57.6 \%$. Mallow seeds containing $20 \%$ oil are used as cattle feed. Milled or steamed seeds are recommended in as feed for pigs, and dry intact seeds - for birds. In its pure form mallow ensiled bad, especially in the early stages of the plant development, so for silage it is suitable only in fruiting stage when the actual sugar content exceeds the minimum sugar. Inclusion in the diet of lactating cows to $20 \mathrm{~kg}$ of the mallow silage increases milk production (0.4-0.5 kg per day), milk fat, and weight gain of the animals. Mallow is an excellent protein component for making different kinds of mixed silage (Kshnikatkina et al., 2005).

In the N.N. Grishko National Botanical Garden of National Academy of Sciences of Ukraine the biological basis for the introduction and cultivation of mallow were developed, as well as highly resistant sorts based on this species and its hybrids were created - these are 'Silva' $(M$. pulchella), 'Ryuzana' (M. meluca Graebn. $\times$ M. pulchella), 'Nicka' (M. pulchella $\times$ M. crispa L.). These sorts are characterized by high yield aboveground biomass (from 54.6 to $99.8 \mathrm{t} / \mathrm{ha}$ ), a valuable chemical composition (protein content - 12,1-25,6\%, ascorbic acid - 181,7-353,0 mg\%) and provide a way out of absolutely dry matter from 11.46 to 21.33 $\mathrm{t} /$ ha of fodder units - 10,08-17,49, protein - 1,92$2,64 \mathrm{t} / \mathrm{ha}$. Species have high seed yield (1,23-2,13 $\mathrm{t} / \mathrm{ha}$ ) and a reproduction rate (242-355) (Rakhmetov, 2001).

The aboveground portion of $M$. verticillata is rich in polysaccharides. Seeds contain fatty oil, polysaccharides, flavonoids, tannins and terpenoids (Vegetable..., 1986; 
Enkhmaa, 2005).

Medications from the above-ground portion of $M$. verticillata have anti-inflammatory activity, immune stimulating and diuretic (Enkhmaa, 2005). Mallow herb is a part of traditional Tibetan recipes: Jamba-6, Sema-3, Altan els-8, Buurnii arur18, Jamba-2, Sojid, Sugmel-10, Umodeujin-24, Vanlag-37, Goui-5, Zagtar-7, Sembu-11, Serjijima13, Arur-15 (Medicinal..., 2013).

The extract derived from seeds of $M$. verticillata is promising for the treatment of metabolic diseases, including type II diabetes and hyperlipidemia (Tomoda et al., 1991; Jeong et al., 2011). Leaves and flowers should be used as an emollient, for gargling and poultices (Vegetable ..., 1986).

\section{Vicia hirsuta(L.) S.F. Gray}

Annual plant 20-90 cm in length. Stems are quadrangular, branched from the base, prostrate or ascending, pubescent, thin. Leaves having 4-8 pairs of linear leaflets 5-20 mm long, 1-3 mm wide, on the top truncated, with a wide tip, notched or rounded, bare or hairy beneath. The axis of the leaf ends with branched tendril. Lateral veins are inconspicuous. Stipules semisagittate, its lobes are narrow linear or broadly lanceolate. Peduncles are longer than leaves, from sinuses of which they emerge. Raceme is 3-5-flowered. Flowers are small, 3-4 mm long, whitish with purple spots. Calyx teeth are of equal long, subulate, acute, nearly equal to the corolla. Banner is widely clawed, bent from the keel and is slightly longer than the latter. The column is compressed from the back, bared. Mature beans are brown-black 8-10 mm long, 3-4 mm wide, rhombic, densely hairy, 2-seeded (Nikiforova, 1994). Seed is 2-2,8 $\mathrm{mm}$ in length and width 1.8-2 mm thick, round-flattened or thickenedlenticular. Cicatrix is linear, $2 \mathrm{~mm}$ in length equal to $1 / 3$ of the circumference of the seed. Often there is a brown cicatrix cord with a length of $2 \mathrm{~mm}$. The surface is a light-gray-green, dark brown and black spots, shiny, smooth (Brouwer, Staehelin, 2010).

Vicia hirsuta has a Western Palearctic area covering Europe, West Asia and North Africa (Fedtschenko, 1934). To date the species is distributed almost all over the globe due to its introduction in the culture as fodder plant, as well as by inadvertent penetration with the seeds of cultivated plants. So, in the northeast of North America (Canada, Quebec) this species was recorded already in 1861, but the way of its penetration is unknown (Lavoie et al., 2012).The most likely way to spread is by speirochoria. Vicia hirsuta was widespread in crops of winter crops in Belarus in the 30s of the last century, virtually disappeared in 50 years. Its disappearance of crops is associated with the improvement of treatment of seeds and farming. It was also affected by the changes in the structure of sown areas in the postwar years (reduction of grain and flax, the expansion of cultivated) and increased use of herbicides 2,4-D group, 2M-4Ch, simazine and others (Soroka et al., 2011).

In Central Europe Vicia hirsuta is one of the diagnostic species of alliance Scleranthion annui (Kruseman et Vlieger 1939) Sissingh in Westhoff et al. 1946 - community of crop weeds that are usually formed in acidic nutrient-poor soils in cool areas with high rainfall (Lososova et al., 2006; Chytrý, 2009). The species is a widespread weed in the European part of Russia (AgroAtlas, 2009). In some areas of the European part of Russia (for example, in the Ryazan region) $V$. hirsuta belongs to the group of adventitious species that actively settled and naturalized by anthropogenically disturbed habitats (Khorun, Kazakova, 2013). In the eastern part of Primorye Territory (Far East) in secondary habitats far from human dwellings (slopes of roads, quarries, etc.) many communities of different species Vicia («the kingdom of vetches”) including $V$. hirsuta are widespread (Ulyanova, 2005).

In Siberia, the species was first found in 1885 in Tyumen Region. In 1912, the species was found in the Tomsk Region, and later - in the Omsk Region and Irkutsk Regions (Krylov, 1933). By the 60th years of XX century V. hirsuta was found in the Novosibirsk Region, Krasnoyarsk Territory and Buryatia (Sergievskaja, 1964).

The first mention of the species growing in the Altai, without specifying the exact location, was appeared in "Flora of the USSR" (Fedtschenko, 1948). Now the species is found in the western part of the Altai Territory albeit rarely. In the eastern part of the region until recently it was known only in the Altai district (Silantieva, 2006). The new location of $V$. hirsuta in Altai Territory and Republic of Altai, discovered in recent years (Zykova, 2012, 2015), indicate a further dispersal of the species in Altai. Now this species 
is distributed in all regions of Siberia, except the Arctic (Nikiforova, 1994; Yakovlev, Sytin, Roskov, 1996). In the north-western part of the Altai-Sayan province species grows in a number of botanicalgeographical districts: common in the Kuznetsk Basin and Kolyvan-Tomsk plateau; rarely - in the Northwest Altai, Nazarovsky-Minusinsk Basin and Salair Ridge (Ebel 2012).

At the beginning of the XX century, only two locations of this species on the territory of the Tomsk region were known (Krylov, 1933). In 50s of $\mathrm{XX}$ century, it was first discovered in the territory of Shegarsky and Molchanovskiy districts, where it was stated as a rare weed in cereal crops (Kachaeva, 1950). A.V. Polozhij (1954) listed it among weed species of the Tomsk region that occurring sporadically in agricultural crops. In our study of households of Tomsk Region in 20032005, Vicia hirsuta was detected in several administrative districts in the crops of oilseeds (Rape, Camelina, Wild Turnip, White Mustard). Currently, it is quite common in all parts of the Tomsk region, where there is the development of crop production. As invasive weed it is found in crops of spring and winter crops, on the outskirts of the fields on deposits, roadsides. In the south of Tomsk Region it has been repeatedly noticed in the meadows.

Now in Siberia a regularly penetration of seeds of $V$. hirsuta by the seed lots of different cultures is happening. Resulting to the gerbological analysis its seeds were found in seed of honey plants, oil plants, and forage crops (Wild Turnip, Rape, Camelina) cultivated in the Tomsk region. One of the factors contributing to the spread of this species on the territory of the Tomsk Region is actively developing of beekeeping in the last decade. Permanent demand for seeds of honey crops such as Sinapis alba and Phacelia tanacetifolia, and the delivery of them from different regions of Siberia and the European part of Russia, promote regular bringing of seeds of Vicia hirsuta into Tomsk region (Mikhaylova, 2011).

Vicia hirsuta is a spring or winter annual plant. Flowers and fruits are from July to August. Seeds are ripening not simultaneously. Seed production is low - no more than 100 seeds per plant (Kurdyukova, Konoplia, 2014). The features of dissemination offer the completion of the soil seed bank by barohoria and spread by speirochoria. The populations of the species confined to the meadow and steppe phytocoenoses seeds germinate in unison only conducive to the good for seedlings years with high humidity. Such coenopopulations are characterized by changing an active state at rest when they consist only (or mainly) of viable seeds in the soil (Kurkin, 1976; Rabotnov, 1983). The species is characterized by polyalternativeness of the ontomorphogenesis associated with the ability of seeds to germinate throughout the growing period (Sheipak, 2001).

The species is characterized by seed solidity. Seeds are characterized by physical dormancy, for interrupting of which the treatment by scarification is necessary. In uncontrolled conditions in laboratory storage seeds can remain viable for more than 10 years. According to our data, the viability of seeds stored for 12 years, is $90 \%$.

Vicia hirsuta relates to a small number of aggressive species. Growing in segetal and ruderal communities, this species does not form continuous thickets oppressing other. However, in field of such thin-stalked crops like Flax and Camelina, Vicia sprouts can cause mechanical damage, crisscrossing the cultivated plants, and create difficulties in harvesting. The most harmful is the ability to clog the seeds of cultivated plants. This is a typical speirochorous weed (Kucewicz et al., 2010). Its seeds are difficult to separate of the fineseeded cultures (Rape, Mustard, Camelina, Phacelia, etc.). Seeds of Vicia hirsuta during the First World War were used in Germany for food (after soaking in soda). It is used as a fodder plant and green manure (Wolfe, Maleeva, 1969).

\section{CONCLUSION}

The review of information on two invasive species of Siberia - Malva verticillata L. and Vicia hirsuta (L.) S.F. Gray gives an idea of intensive resettlement of these species in Siberia, which began in the late twentieth century. Particular attention should be paid to the active distribution of these species in Siberia agrocoenoses with seeds of field crops (oil and honey).These plants appropriate to examine as a model of invasive species. 


\section{ACKNOWLEDGMENTS}

This research carried out in 2015 was supported by "The Tomsk State University Academic D.I. Mendeleev Fund Program” grant (8.1.79.2015).

\section{REFERENCES}

1. Brouwer, B. \& Shtelin, A., Guide to Seed of agricultural, forest and ornamental plants with the key to determine the most important seed (p. 694). M: KVM Partnership scientific publications, 2010.

2. Vinogradova, Yu. K., Majorov, S.R., Notov, A.A. Black Book of flora of the Tver region: alien plant species in the ecosystems of the Tver region 2011; 292. M.: Association of scientific publications of KMK.

3. Vinogradova, Yu.K., Majorov, S.R. \& Khorun, L.V., Black Book of flora of Central Russia (Alien species in the ecosystems in Central Russia) 2009; 494. M.: GEOS.

4. Vlasenko, N.G., Vlasenko, A.N., Sorokin, T.P. \& Kudashkin, P.I., Weed plants and their control in the cultivation of crops in Siberia 2007; 128. Novosibirsk.

5. Vlasova, N.V., Family Malvaceae. Flora of Siberia 1996; 66-71. Nauka, Novosibirsk.

6. Wulf, E.V. \& Maleeva, O.F., Global resources of useful plants 1969; 566. L.: Nauka.

7. Zykova, E.Y., New finds of adventitious species in the Altai. Plant world of Asian Russia, 2012; 1(9): 50-54

8. Zykova, E.Y., Adventive flora of the Altai Republic. Plant world of Asian Russia, 2015; 3(19): 72-87.

9. Kasarin, V.F., Kazarina, L.F., Frolova, A.V., Gutsalyuk, M.I., Agliulina, L.K. \& Abramenko, I.S., Recommendations of mallow cultivation for seeds and forage in the forest of the Middle Volga 2009; 17. Kinel.

10. Kachaeva, Z.F., Weediness of some areas of the Tomsk region 1950; 5-30. Notes of TGPI.

11. Koroleva, A.S., Krasnoborov, I.M. \& Penkovskaya, E.F., Guide to the Plants of the Novosibirsk region 1973; 368. Nauka, Novosibirsk.

12. Krylov, P.N., Flora of Western Siberia 1933; 1449-1817. Tomsk.

13. Sergievskaja, L.P., Flora of Western Siberia 1964; 3255-3550. Tomsk.

14. Korotkova, O.N. \& Konoplia, N.I., Seed production of different weed species. Plant Protection News, 2014; 1: 30-35.
15. Kurkin, V.A., System study of the dynamics of meadows. M.: Nauka, 1976.

16. Kshnikatkina, A.N., Gushina, V.A., Galiullin, A.A., Varlamov, V.A. \& Kshnikatkin, S.A., Nontraditional fodder crops: a textbook. Penza: RIO PGSHA, 2005.

17. Majevski, P.F., Flora of middle part of the European part of Russia. M.: Association of scientific publications of KMK, 2006.

18. Majorov, S.R., Bochkin, V.D., Nasimovich, J.A. \& Scherbakov, A.V., Adventive flora of Moscow and the Moscow region. M.: Association of scientific publications of KMK, 2012.

19. Maisuryan, N.A. \& Atabekova, A.I., The determinant of seeds and fruits of weeds. M.: Kolos, 1978.

20. Mikhailova, S.I., Weeds in seed lots oilseeds. Scientific statements BSU. Series: Natural sciences, 2011; 9(104), 268-271.

21. Nikiforova, O.D., Vicia L. Flora of Siberia. Nauka, Novosibirsk, 1994.

22. Nikolaeva, M.G., Razumov, M.V. \& Gladkova, V.N., Reference germination of dormant seeds. L.: Nauka, 1985.

23. Olyanitskaia, L.G. \& Tzvelev, N.N., Malvaceae Juss. Flora of Eastern Europe. SPb.: Peace and family 1996; 95.

24. Krasnoborov, I.M., Guide to the Plants of the Kemerovo region. Novosibirsk, 2001.

25. Polozhij, A.V., Weeds of Tomsk region and the fight against them 1954; 96. Tomsk: Publishing house of Tomsk University Press.

26. Popov, M.G. Flora of Central Siberia. L.: Publishing House of the USSR Academy of Sciences.

27. Rabotnov, T.A., Phytocoenology. M.: Publishing House of Moscow University, 1983.

28. Plant resources of the USSR: Flowering plants, their chemical composition, the use. Family Paeoniaceae - Thymelaeaceae., L.: Nauka, 1986.

29. Rakhmetov, D.B., Biological characteristics of species of the genus Malva in connection with the introduction to the culture in a forest-steppe of Ukraine. Mater. VIII Vseros. Symposium, 1993.

30. Rakhmetov, D.B., Biological bases of introduction and cultivation of annual and perennial species of family Malvaceae in the steppes of Ukraine. PhD thesis. Kiev, 2001.

31. Serykh, G.I., Family Malvaceae. Flora of the Krasnoyarsk Territory. Tomsk: Publishing House of Tomsk University Press, 1977.

32. Silantieva, M.M., Conspectus of the flora of the Altai Territory. Barnaul, 2006.

33. Soroka, S.V., Tsyganov, A.R., Jakimovich, E.A., Soroka, L.I ., Korpanov, R.V. \& Kabzar, N.V., 
Trends cenoses weeds in crops of winter crops in the conditions of Belarus. News of National Academy of Sciences of Belorussia. Series of Agrarian Science, 2011; 2: 46-54.

34. Ulyanova, T.N., Weeds in the flora of Russia and neighboring countries. Barnaul: Publishing House “AzBuka”, 2005.

35. Fedchenko, B.A., Vicia L. Weed plants of the USSR, 1934.

36. Fedchenko, B.A., Vicia L. Flora of the USSR. L.: Publishing House of the USSR Academy of Sciences, 1948.

37. Khorun, L.V. \& Kazakov, M.V., The floristic composition and naturalization of adventive flora of the Ryazan region. Bulletin of Udmurt University, 2013; 2: 44-47.

38. Tzvelev, N.N., New combinations of taxa of vascular plants. News of taxonomy of higher plants, 2000; 32: 181-185.

39. Cherepanov, S.K., Vascular plants of Russia and adjacent states (the former USSR). Russian edition. SPb, 1995.

40. Shaulo, D.N., Artemov, I.A., Doduk, A.D. \& Molokova, N.I., Floristic records in the Republic of Tyva. Turczaninowia, 2006; 9(3): 90-98.

41. Shaulo, D.N., Zykova, E.Y., Drachov, N.S., Kuzmin, I.V. \& Doronkin, V.M., Floristic records in the Western and Central Siberia. Turczaninowia, 2010; 13(3): 77-91.

42. Sheipak, A.A., Features of the age structure of annual species of Vicia L. Proceedings of the 6th Intern. Conf. on plant morphology memory to I.G. Serebryakov and T.I. Serebryakova. M, 1999.

43. Ebel, A.L., Conspectus of the flora of northwestern part of the Altai-Sayan province 2012; 568. Kemerovo KREOO “Irbis".

44. Ebel, A.L. \& Nekratova, N.A., The flora of the neighboring territories of village Efremkino (Kuznetsk Alatau, Khakassia). Bot. Journ., 1996; 81(12), 97-111.

45. Ebel, A.L., Strelnikova, T.O., Kupriyanov, A.N., Anenkhonov, O.A., Ankipovich, E.S., Antipova, E.M., Verkhozina, A.V., Efremov, A.N, Zykova, E.Y., Mikhailova, S.I., Plikina, N.V., Ryabovol, S.V., Silantieva, M.M., Stepanov, N.V., Terekhina, T. C., Chernova, O.D. \& Shaulo, D.N. Invasive and potentially invasive species in Siberia. Bulletin of the Main Botanical Garden, 2014; 1: 52-62.

46. AgroAtlas (Interactive Agricultural Ecological Atlas of Russia and Neighboring Countries. Economic Plants and their Diseases, Pests and Weeds), 2003-2009. Retrieved September 18, 2015 from http://www.agroatlas.ru/en/
47. Chytrý, M., Vegetace Èeské republiky. 2, Ruderální, plevelová, skalní a su•ová vegetace [Vegetation of the Czech Republic. 2, Ruderal, weed, rock and scree vegetation] 2009; 524. Praha: Academia.

48. Danert, S., Zur Morphologie und Systematik von Malva verticillata L. Die Kulturpflanze, 1966; 14(1): 495-510.

49. D’Antonio, C. \& Meyerson, L.A., Exotic Plant Species as Problems and Solutions in Ecological Restoration: A Synthesis. Restoration Ecology, 2002; 10(4): 703-713.

50. Enkhmaa, G., The pharmacological and phytochemical investigation of Malva mohileviensis Downar. Phd thesis. Ulaanbaatar: Health Sciences University of Mongolia, 2005.

51. Hejda, M. \& Pyšek, P., What is the impact of Impatiens glandulifera on species diversity of invaded riparian vegetation? Biological Conservation, 2006; 132: 143-152.

52. Jeong, Y. T. \& Song, C.H., Antidiabetic activities of extract from Malva verticillata seed via the activation of AMP-activated protein kinase. $J$. Microbiol. Biotechnol., 2011; 21(9).

53. Kloot, R.M., Early records of alien plants naturalised in South Australia. J. Adelaide Bot. Gard., 1983; 6(2): 93-131.

54. Kucewicz, M., Maækiewicz, K. \& •róbekSokolnik, A., Selected aspects of tiny vetch [Vicia hirsuta (L.) Gray S.F.] seed ecology: generative reproduction and effects of seed maturity and seed storage on seed germination. Acta agrobotanica, 2010; 63(1): 205-212.

55. Lavoie, C., Saint-Louis, A., Guay, G. \& Groeneveld, E., Les plants vasculair esexotiques naturalis ées: une nouvelle liste pour le Québec. Le naturalist canadien, 2012; 3: 6-32.

56. Lososová, Z., Chytrý, M., Cimalová, Š., Otýpková, Z., Pyšek, P. \& Tichý, L., Classification of weed vegetation of arable land in the Czech Republic and Slovakia. Folia Geobotanica, 2006; 41: 259-273.

57. Medicinal plants in Mongolia. Geneva: World Health Organization. 2013.

58. Mucina, L., Conspectus of classes of European vegetation. Folia Geobot., 1997; 32(2): 117-172.

59. Nghiem, L.T.P., Soliman, T., Yeo, D.C.J., Tan, H.T.W. \& Evans, T.A., Economic and Environmental Impacts of Harmful NonIndigenous Species in Southeast Asia. PLoS ONE, 2013; 8(8): e71255.

60. Pimentel, D., McNair, S., Janecka, J., Wightman, J. \& Simmonds, C., Economic and environmental threats of alien plant, animal, and microbe invasions. Agriculture, Ecosystems and Environment, 2001; 84: 1-20. 
61. Pimentel, D., Zuniga, R. \& Morrison, D., Update on the environmental and economic costs associated with alien-invasive species in the United States. Ecological Economics, 2005; 52: 273-288.

62. Randall, R.P., A Global Compendium of Weeds. 2nd Edition 2012; 1119. Department of Agriculture and Food, Western Australia.

63. Richardson, D.M., Holmes, P.M., Esler, K.J., Galatowitsch, S.M., Stromberg, J.C., Kirkman, S.P., Pysek, P. \& Hobbs, R.J., Riparian vegetation: degradation, alien plant invasions, and restoration prospects. Diversity and Distributions, 2007; 13: 126-139.

64. Tomoda, M. \& Shimizu, N., Anticomplementary and hypoglycemic activities of the glucans from the seeds of Malva verticillata. Kitasato Arch. Esp. Med., 1991; 64(4): 315-316.

65. Winter, M., Schweiger, O. \& Klotz, S., Plant extinctions and introductions lead to phylogenetic and taxonomic homogenization of the European flora. Proceedings of the National Academy of Sciences of the United States of America, 2009; 106: 21721-21725.

66. Ya, T., Gilbert, M.G. \& Dorr, L.J., Malvaceae Flora of China. Beijing: Science Press, and St. Louis: Botanical Garden Press, Missouri, 2007; 264-298.

67. Yakovlev, G.P., Sytin, A.K. \& Roskov, Yu.R., Legumes of Northern Eurasia. Kew: Royal Botanic gardens, 1996; 724. 